
na przykładzie Ogrodu Barbakan

\title{
Changes of Planty Garden's composition in Cracow, example of Barbakan Garden
}

\section{Streszczenie}

Planty to pierścień zieleni wokół Starego Miasta Krakowa, założony w XIX wieku. Na przestrzeni lat park zmieniał swoją kompozycję, ale niezależnie od przekształceń Planty są jednym z najważniejszych i najcenniejszych terenów zieleni w Krakowie. Ze względu na wyjątkowy charakter zostały one wpisane na listę światowego dziedzictwa UNESCO wraz ze Starym Miastem. Praca ma na celu ukazanie przemian parku w odniesieniu do zmieniających się kanonów piękna na podstawie wybranego fragmentu Plant.

Słowa kluczowe: Planty Krakowskie, zieleń publiczna, zieleń zabytkowa, UNESCO, park historyczny

\section{Abstract}

The Planty Garden in Cracow is the belt of greenery around The Old Town, that was formed in $19^{\text {th }}$ century. Over the years the garden's composition has been changed but independently of those changes, 'green ring' is one of the most important and valuable public greenery in the city. As an integral part of the Historic Centre of Cracow the Planty Garden was scheduled into UNESCO World Heritage List. This work shows character of those transformations with reference to beauty principles changes.

Keywords: Planty Garden, historical greenery, green public spaces, UNESCO, historical park 


\section{WPROWADZENIE}

Planty Krakowskie to obszar zieleńców publicznych o nieregularnym kształcie zbliżonym do elipsy, stanowiących pierścień wokół najstarszej części miasta Krakowa. Nieprzerwany ciąg zieleni od wewnętrznej strony przylega do zabudowań Starego Miasta, od zewnątrz ograniczony jest ulicami tworzącymi tzw. I obwodnicę Krakowa i łączy się na południu z otoczeniem Wawelu i jego zadrzewieniami. Dzisiejszy obszar plant to miejsce dawnych murów obronnych, stanowiących pierścień fortyfikacji wokół dawnego miasta. Mury te powstawały etapami już od końca XIII wieku poprzez wiek XIV i XV. Od II połowy XVIII wieku popadły w ruinę i przestały pełnić swoją funkcję militarną, która notabene traciła na znaczeniu. Rozbiórkę murów, baszt i bastionów zaczęto już w 1806 roku, jednak w drugiej dekadzie XIX wieku wniesiono oficjalny projekt mówiący o stworzeniu ogrodów w miejscu fortyfikacji. Franciszek Klein w swojej książce dotyczącej Plant Krakowskich pisze: „[...] wytknięto jasny cel [...]. Mianowicie w r. 1820 prezes Senatu Rządzącego, Stanisław hr. Wodzicki postawił wniosek o urzq̨dzenie

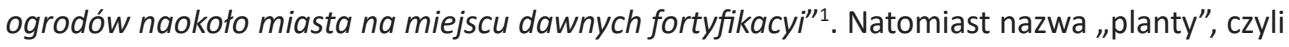
„plantacje”, pochodzi od słowa „plantować”, co dosłownie oznacza „wyrównywać teren”2. Nie ma ono zbyt wiele wspólnego ze sztuką ogrodową, ale odnosi się do czynności, które zapoczątkowały powstanie Plant, czyli do niwelacji murów, fos i nierówności terenu, które składały się na fortyfikacje wokół starego miasta. Nazwa „Planty” uformowała się nieformalnie przez odwiedzające ogrody kobiety z dziećmi i robotników pracujących przy „plantunku”, ale po jakimś czasie zaczęła być używana powszechnie i stała się oficjalną nazwą.

W zależności od miejsca powstałe Planty miały szerokość od ok. 50 do 100-140 m, a cała długość pasa zieleni wynosiła wtedy ok. $4 \mathrm{~km}^{3}$. Na przestrzeni lat Planty ulegały przekształceniom, jednak ich pierwotny kształt pierścienia został zachowany i obecnie w zależności od odcinka szerokość pierścienia wynosi od 40 do 120 m, a całość powierzchni to 21 ha.

\section{RYS HISTORYCZNY KSZTAŁTOWANIA KOMPOZYCJI PLANT}

Podstawowe tworzenie się kompozycji plant można „sztucznie” podzielić na 2 etapy, tj. od początków formowania się zieleńców do 1847 roku, następnie od lat 70. do końca XIX wieku, gdyż właśnie w tych okresach można wyróżnić najbardziej charakterystyczne przekształcenia, biorąc pod uwagę ogół plant. Pomiędzy wyróżnionymi etapami nie było znaczących zmian, a prace $w$ przestrzeni Plant polegały raczej na pielęgnacji roślin i elementów małej architektury. Z początkiem wieku XX do czasów współczesnych kompozycja zieleńców także nie podlegała drastycznym zmianom, dlatego też po upływie ponad 200 lat Planty nadal zachowują kształt podobny do tego, jaki był pierwotnie.

Początki powstawania ogrodów nawiązują do idei klasycystycznych, tj. prostych, geometrycznych form. Wzdłuż parku, zaczynając od Wawelu i na Wawelu kończąc, poprowadzono 
główną, szeroką ścieżkę, okalającą całe Stare Miasto. Wyznaczano reprezentacyjne kręgi, od których rozchodziły się poszczególne aleje, także geometryczne kwatery były obsadzane drzewami. Stawiano na powiązania widokowe wyznaczanych alej przecinających planty, które były najczęściej przedłużeniem dochodzących do parku ulic. Natomiast pomiędzy alejami tworzono obszerne trawniki. Początkowo planty obsadzono topolami i kasztanowcami. Wybór gatunków był pokierowany pobudkami praktycznymi - topole jako drzewa łatwo i dynamicznie rosnące nadawały się do osiągnięcia szybkiego efektu zadrzewienia. Po jakimś czasie topole ścinano, aby dać kasztanowcom przestrzeń do rozwoju, a dodatkową korzyścią wynikającą z tego było pozyskanie drewna opałowego. Oprócz wymienionych już gatunków sadzono również lipy, jesiony i wiązy. W plan wchodziło także obsadzenie plant żywopłotami grabowymi tak, żeby powstała naturalna ściana odgradzająca ogrody od drogi. W I połowie XIX wieku dodatkowym elementem rozgraniczającym planty od drogi, a także ścieżki od trawników, były drewniane barierki w kolorach herbu miasta Krakowa. Wówczas w północno-wschodniej części Plant znajdowały się jeszcze pozostałości wałów obronnych, dlatego też postawiono kamienne mostki, aby połączyć teren parku z resztą miasta. Po usunięciu wałów i wyrównaniu terenu w latach 70. mostki zachowano jako „ozdobne wejścia na planty”. Dwa z nich, jeden przy ul. Lubicz, drugi przy ul. Pańskiej, zachowały się jeszcze do początków XX wieku.

W latach 30. XIX wieku modnym stało się fundowanie kamiennych ław stawianych na terenie Plant w ramach "oddolnej inicjatywy” ich upiększania ${ }^{5}$. Ostatecznie liczba ław nie była duża, a już w połowie XIX wieku ustawiano ławki drewniane, będące tańszym i szybszym rozwiązaniem. Natomiast ostatnia ława kamienna zachowała się do początku XX wieku we wschodniej części plant, przy słynnej kawiarni Janikowskiego (obecnie Caffe Gallery Zakopianka), która zajęła miejsce po tzw. altanie rządowej, gdzie odbywały się koncerty orkiestry wojskowej. Popularność Plant rosła i stały się one chętnie odwiedzanym ogrodem Krakowa, zyskując miano „salonu Krakowa”. Dlatego też powstawały takie inicjatywy, jak wspomniana już altana, czy liczne cukiernie i kawiarnie przyplantowe, pojawiające się przede wszystkim w II połowie XIX wieku, które odgrywały znaczącą rolę w życiu społecznym i towarzyskim Krakowa, a szczególnie w świecie krakowskiej bohemy artystycznej.

Symboliczną datą końca pierwszego etapu formowania się Plant jest śmierć Floriana Straszewskiego w 1847 roku, którego uznaje się za jednego z ojców zielonego pierścienia. Lata przypadające na okres od 1847 do lat 70. XIX wieku charakteryzują się lekką stagnacją i brakiem rozwojowego podejścia do kompozycji Plant. Podstawowe prace zostały ukończone i skupiano się na pielęgnacji roślinności oraz dbaniu o elementy małej architektury, takiej jak mostki, ławki czy barierki. Jednocześnie wraz z połową XIX wieku zmieniły się tendencje w kreowaniu przestrzeni - z klasycystycznych na naturalistyczne, i od około 1870 roku ruszyły pewne zabiegi ingerujące w pierwotnie ukształtowaną kompozycję. Tworzono swobodne wnętrza z samotnikami, a ścieżki i aleje zaczęto prowadzić po łagodnych łukach. Przełomowym momentem w historii Plant, zapoczątkowującym ostateczne formowanie się kompozycji, było powołanie w 1879 roku na stanowisko kierownika zarządu plantami Bolesława Maleckiego, wtedy to 
„[...] zaczyna się gorączkowa praca we wszystkich kierunkach”6. Za sprawą Maleckiego Planty nabierały kolorów, pojawiały się liczne rabaty, kwietniki i różaneczniki. Przede wszystkim klombami kwietnymi ozdabiane były miejsca wokół stających w parku od 1874 roku pomników osób zasłużonych, społeczników, poetów, czy też postaci z dzieł narodowych wieszczy. Natomiast ogólna kompozycja Plant uległa przekształceniom w stylu neoromantycznym, czego przykładem jest także fragment z sadzawką przy Barbakanie, dawniej zwanym Rondlem. Z działalnością Maleckiego łączą się liczne dosadzenia drzew, nie tylko już wykorzystywanych gatunków, ale także drzew uznawanych ówcześnie jako gatunki rzadkie, takich jak platan, cis czy robinia. W zieleń Plant wprowadzono także nasadzenia kęp krzewów oraz gatunków egzotycznych i cieplarnianych, modnych w tamtym czasie. Rośliny oranżeryjne pojawiły się przede wszystkim w zieleni towarzyszącej pomnikom jako elementy dekoracyjne. Stosowano takie gatunki jak: palmy, draceny czy agawy.

W II połowie XIX wieku do elementów małej architektury Plant dodano drewniane ławki, które zastąpiły wspomniane wcześniej ławy kamienne. Około 1879 roku pojawiły się na Plantach lampy elektryczne, co jednocześnie czyniło Kraków jednym z pierwszych miast Europy, które wprowadziły takiego rodzaju oświetlenie w przestrzeni miejskiej.

Wraz z końcem XIX wieku skończył się także okres największych przekształceń formujących ogólną kompozycję Plant. Jednocześnie przełom XIX oraz XX wieku to czas bogatego życia towarzyskiego i kulturowego, skupiającego się w przyplantowych kawiarniach, instytucjach kulturowych i innych inicjatywach towarzyszących spotkaniom na terenie zieleńców. W pierwszych dekadach XX wieku, w tym w okresie I wojny światowej oraz międzywojniu, na terenie Plant niewiele się zmieniło. Przekształcenia Krakowa w tamtym czasie dotyczyły raczej najbliższego otoczenia parku niż jego samego. W myśl rozbudowy Krakowa, której inicjatorem był ówczesny prezydent Juliusz Leo, tereny przylegające do pierścienia wokół Starego Miasta od zewnętrznej strony, dotąd o charakterze wiejskim, zaczęto stopniowo przekształcać i integrować z miejską zabudową. W tym nurcie, rozbudowywano strategiczne miejsca przylegające do ulicy otaczającej Planty, chcąc nadać tej okolicy wielkomiejski, monumentalny charakter. W 1939 roku w wyniku sytuacji politycznej i zbliżającej się wojny teren Plant wykorzystano pod usytuowanie rowów przeciwlotniczych. Z kolei w czasie Il wojny światowej i w czasach powojennych Planty zostały fragmentarycznie zniszczone i uległy ogólnemu zaniedbaniu, jednak żadne drastyczne zmiany ingerujące w ich strukturę nie nastąpiły.

Dopiero w latach 70. XX wieku wytyczono projekt rewaloryzacji oraz rekompozycji Plant Krakowskich, którym zajmował się zespół pod przewodnictwem architekta Janusza Bogdanowskiego. W celach projektowych Planty zostały wtedy podzielone na 8 części-ogrodów. Podział ten jest w zupełności ahistoryczny i miał na celu jedynie funkcję porządkującą, a nie nawiązanie do historii zieleńców. Wydzielono takie ogrody jak: Ogród Wawel, Ogród Stradom, Ogród Gródek, Ogród Dworzec, Ogród Florianka, Ogród Pałac Sztuki, Ogród Uniwersytet oraz Ogród Barbakan, który posłuży jako przykład widocznych śladów nawarstwień kompozycyjnych na Plantach w dalszej części pracy. 


\section{ANALIZA KOMPOZYCJI OGRODU BARBAKAN}

Kształtowanie krajobrazu Plant nawiązywało do zmieniających się tendencji oraz kanonów piękna, jakie panowały w danym czasie. Jednocześnie park i jego przestrzeń kreowały lub miały wpływ na kreowanie się kanonów piękna w sztuce projektowania terenów zieleni publicznych. W przestrzeni Plant można doszukać się wielu śladów przemian, jakie się tam dokonywały, a jednym z lepszych przykładów tego zjawiska jest Ogród Barbakan.

Ogród Barbakan znajduje się w północnej części Plant Krakowskich, a jednymi z ważniejszych kwestii tego wnętrza architektoniczno-krajobrazowego są ściany, które go tworzą. Z całego pierścienia fortyfikacji ocalała jedynie Brama Floriańska z przylegającym do niej fragmentem murów obronnych, stanowiące południową ścianę wnętrza oraz Barbakan, który jest silną dominantą tego fragmentu Plant. W początkowej fazie kształtowania parku Ogród Barbakan podlegał pod klasycystyczny układ podobnie jak całość zieleńców, czego dowodem są m.in. szeroka aleja okalająca Planty oraz ścieżki prowadzone po linii prostej. Natomiast w wybranych fragmentach można wyodrębnić ślady późniejszego układu naturalistycznego, na co wskazują "okrężne" ścieżki, prowadzone po łagodnych łukach, oraz neoromantyczne wnętrze z sadzawką nawiązujące do stylów Dalekiego Wschodu. Wśród okazów starodrzewia można znaleźć tutaj kasztanowce, klony, jesiony i lipy. Przy głównej alei znajdują się właśnie lipy oraz kasztanowiec, co może świadczyć o zmianach przebiegu ścieżki. Ponadto można znaleźć tutaj także przykłady nasadzeń z zachowanymi z XX wieku tendencjami, kiedy dokonywano prób wprowadzenia na Planty drzew szpilkowych. Większość okazów znajduje się w środkowej części ogrodu, po zachodniej stronie Barbakanu, rosną tu w skupiskach sosny czarne, kilka okazów modrzewi oraz żywotników, a także współczesne nasadzenia cisów przy pomniku Jana Matejki w centralnej części Ogrodu.

W celu dokonania analizy kompozycji Ogrodu Barbakan wykonano próbę waloryzacji poszczególnych elementów ogrodu z jednoczesnym wyodrębnieniem wnętrz o różnym stopniu atrakcyjności (II. 6 i 7). W badaniu wzięto pod uwagę stan zieleni, elementów małej architektury oraz nawierzchni alejek, i ich oddziaływanie na odbiór danego wnętrza. Wnętrza zostały wyodrębnione na podstawie poszczególnych kwater zieleni z elementami kubaturowymi przez poprowadzone ścieżki. Ogółem wnętrza można podzielić na wysoko dekoracyjne oraz te charakteryzujące się średnią dekoracyjnością. Pomimo kilku elementów o niskiej wartości, takich jak zaniedbana zieleń m.in. wokół pomnika Bohdana Zaleskiego lub mało estetycznej kawiarni i jej najbliższego otoczenia, jakim jest pawilon „Łabędzie” z 1930 roku, w Ogrodzie Barbakan nie wyodrębniono wnętrz, które charakteryzowałyby się wyjątkowo niską dekoracyjnością. Ważnym aspektem w ocenie były zabytkowe mury fortyfikacji oraz zabudowa przylegająca do I obwodnicy wraz z placem Matejki, co stanowi ściany tego fragmentu Plant.

W zachodniej części Ogrodu Barbakan znajduje się sadzawka z fontanną i mostkiem stylizowanym na sztukę ogrodową japońską. Do 1879 roku teren, na którym obecnie znajduje się sadzawka, zajmował plac targowy i dopiero w okresie zarządzania plantami przez Bolesława 
Maleckiego część ta została włączona do krakowskiego parku. Mimo że element ten powstał na początku XX wieku, w latach 1904-1905, kiedy już od dłuższego czasu panowały tendencje naturalistyczne, idea kompozycji z sadzawką w takiej formie spotkała się z krytyką. Należy wspomnieć, że oprócz samego kształtu powstanie sadzawki krytykowano ze względu na obawy, że stojąca woda przyczyni się do szerzenia malarii. Dodatek w postaci fontanny został zaprojektowany nie tylko jako element dekoracyjny, ale także przez praktyczne względy, gdyż miał spełniać funkcję „odświeżacza powietrza”. Dodatkowo w późniejszych latach fontanna został wzbogacona o iluminacje. Po przeciwnej stronie mostka znajduje się niewielka wyspa z rosnącymi na niej obecnie pojedynczymi brzozami. Pierwotnie w tym miejscu miała znajdować się gęsta kępa drzew i krzewów. Możliwe, że w którymś okresie formowania tej części rosła tu także wierzba płacząca. Naprzeciwko mostka nad sadzawką znajduje się pomnik Bohdana Zaleskiego, poety z okresu romantyzmu, stanowiący zamknięcie widokowe ścieżki oraz akcent w całym wnętrzu z sadzawką. Na wzór wcześniejszych tendencji projektowania nasadzeń roślinności wokół pomników pod monumentem stworzono porośnięty krzewami okrywowymi okrąg. Warto zaznaczyć, że w przeciągu wieków zmieniły się funkcje przypisywane pomnikom na Plantach. Jak już wspomniano, w XIX wieku miały one przede wszystkim budować poczucie polskości, natomiast obecnie oprócz funkcji dekoracyjnych akcentów stanowią one także pomniki pamięci.

W latach 1945-97 część Ogrodu Barbakan, gdzie obecnie znajduje się pomnik Jana Matejki, posiadała funkcję sepulkralną, ponieważ właśnie tutaj znajdował się niewielki cmentarz żołnierzy radzieckich, a później pamiątkowy pomnik, który wraz ze szczątkami został przeniesiony w 1997 roku na cmentarz Rakowicki.

\section{KONKLUZJE}

Planty stały się swego rodzaju symbolem Krakowa i odgrywają rolę w wielu aspektach życia mieszkańców. Ich wartość nie wynika tylko z tego, jakie korzyści niesie ze sobą obecność terenów zielonych w ścisłym centrum. Na przestrzeni lat zielony pierścień wokół Starego Miasta Krakowa odgrywał i nadal odgrywa rolę miejsca spotkań towarzyskich, spacerów i odpoczynku. Już w pierwszych latach powstania Planty zostały docenione przez mieszkańców Krakowa jako wartość sama w sobie i także dziś stanowią dla miejscowych oraz odwiedzających Kraków nieodłączny element miasta.

Po analizie przemian, jakie dokonywały się w Ogrodzie Barbakan, ale także przekształceń na całości Plant, można stwierdzić, że w ciągu wieków kompozycja parku zmieniała się, nawiązując do różnych stylów panujących w kształtowaniu przestrzeni publicznych. Roślinność oraz dodatkowe elementy współtworzące krajobraz zieleńców odnosiły się do trendów i tendencji obowiązujących w danym czasie, ale także jednocześnie same kreowały pewne kanony piękna, pomimo że na początku często spotykały się z krytyką. Na przestrzeni lat także funkcja niektórych elementów krajobrazu Plant ulegała przekształceniu.

Biorąc pod uwagę szczególny charakter miejsca, kształtowanie przestrzeni na Plantach wymaga wyjątkowego podejścia nie tylko ze względu na przypisany im status zabytku, ale także genius loci, historię oraz współczesną funkcję, jaką Planty spełniają w życiu miasta Krakowa. 
II. 1. Kraków wraz z Plantami w 1899 roku (źródło: http://obserwatorium.um.krakow.pl)

II. 2. Ostatnia kamienna ławka na Plantach (F. Klein, Planty Krakowskie, Kraków 1911, s. 19)
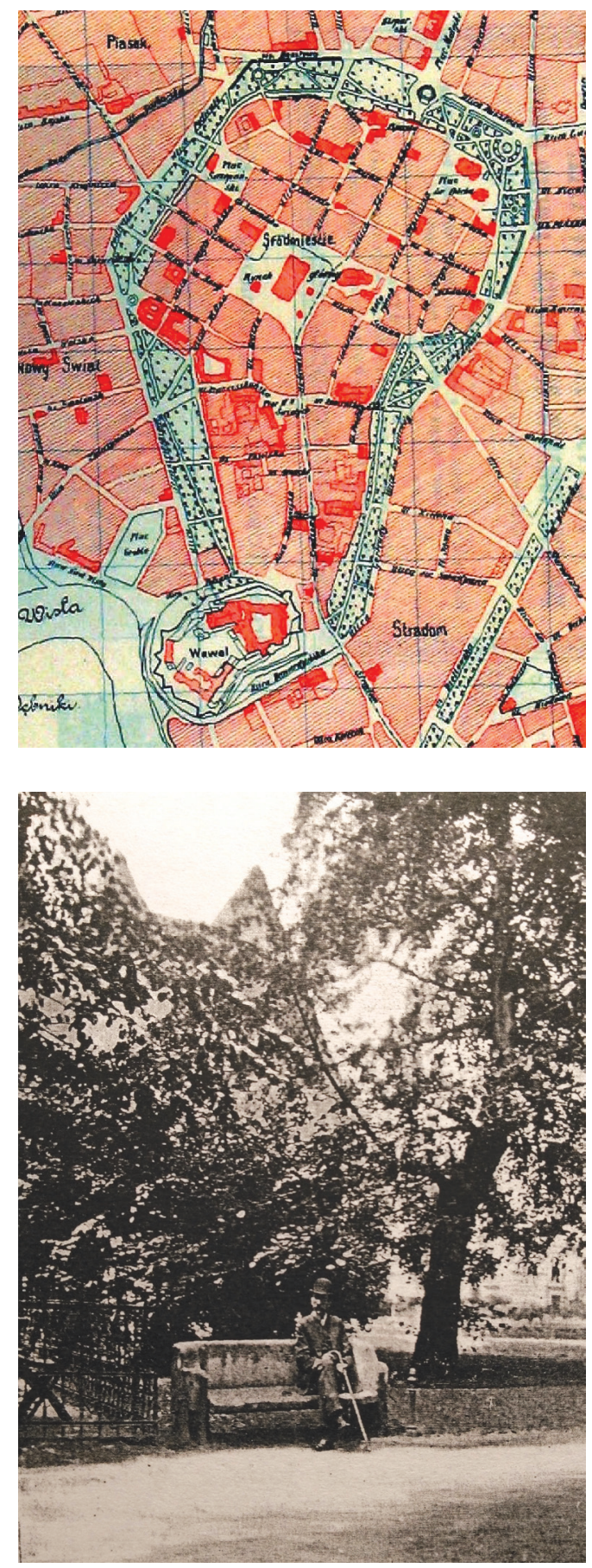


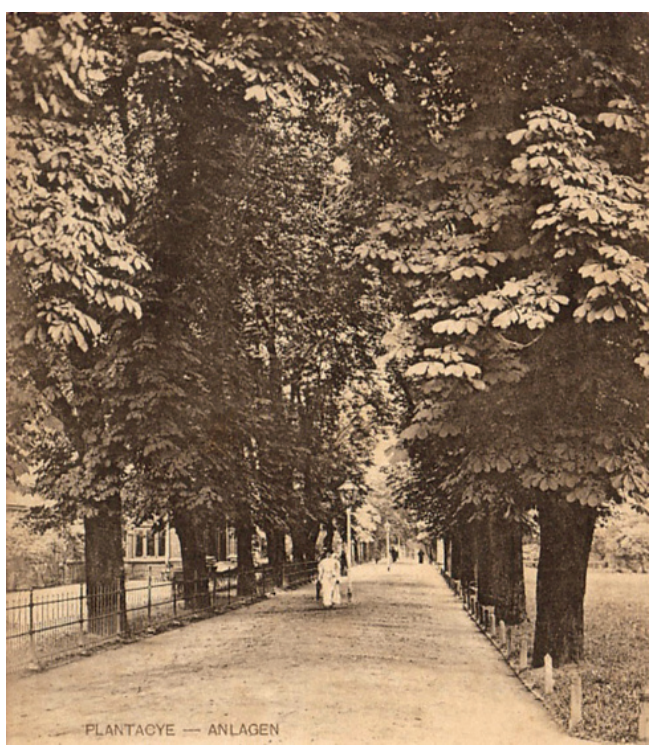

II. 3. Aleja na Plantach, 1898 rok (źródło: https://krakow.fotopolska. eu/509018, foto.html?o=b2254\&p=1)
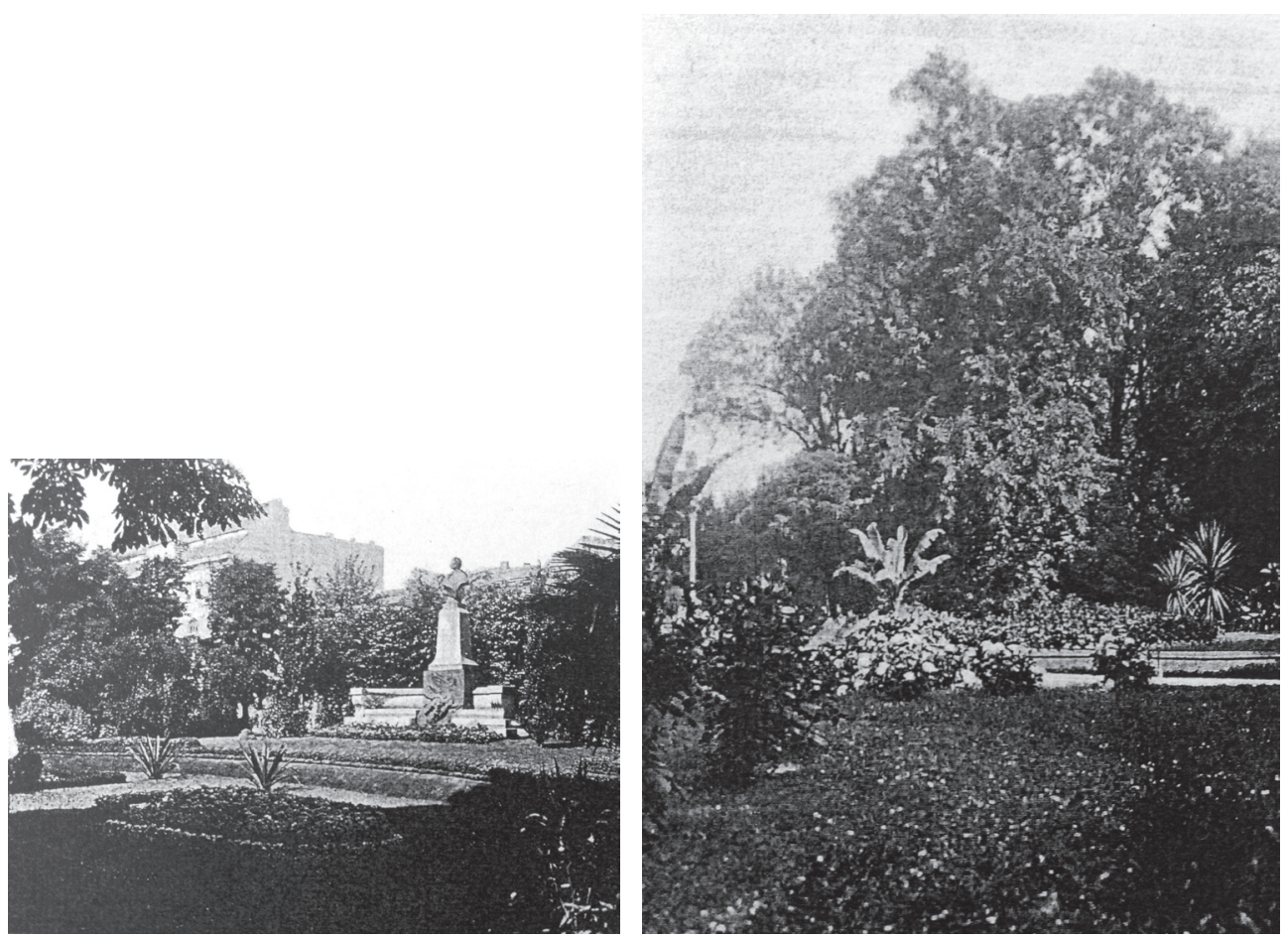

II. 4-5. Klomby przy pomnikach Grottgera oraz Chopina

(F. Klein, Planty Krakowskie, Kraków 1911, s. 32, 34, 59) 


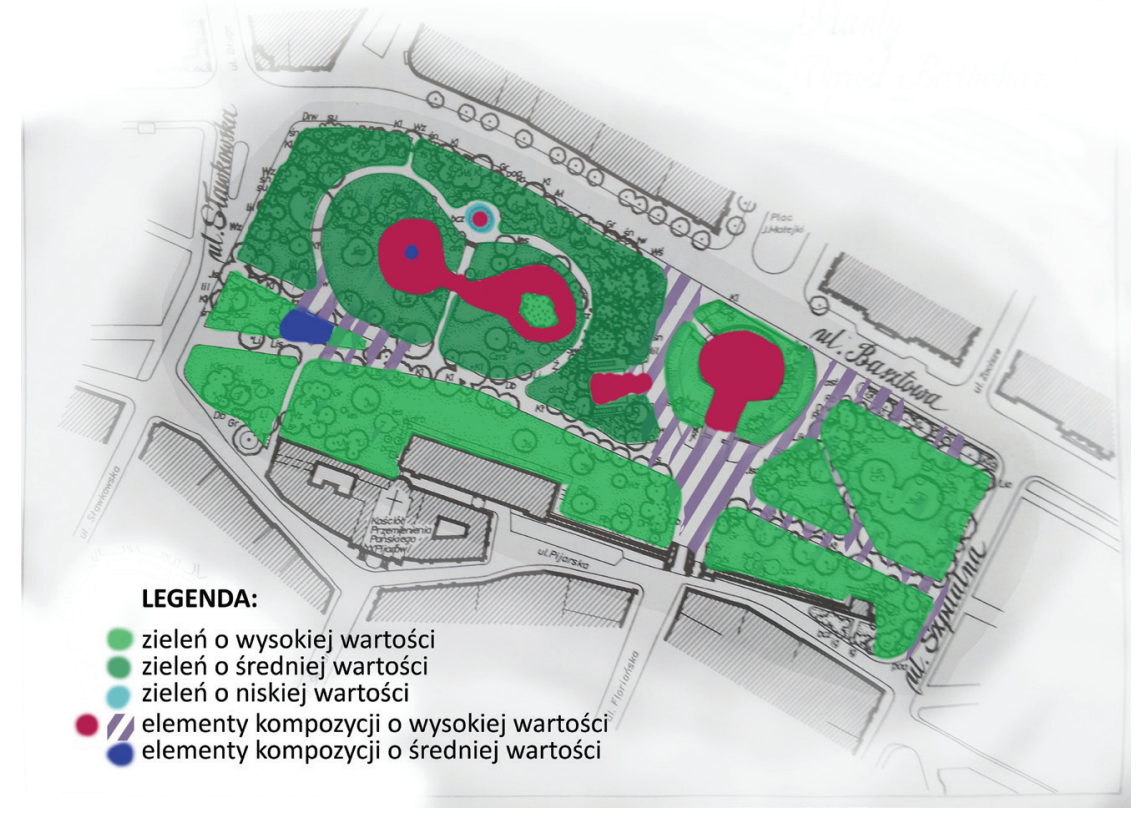

II. 6. Analiza waloryzacji wnętrza krajobrazowego Ogrodu Barbakan (opr. A. Greniuk)

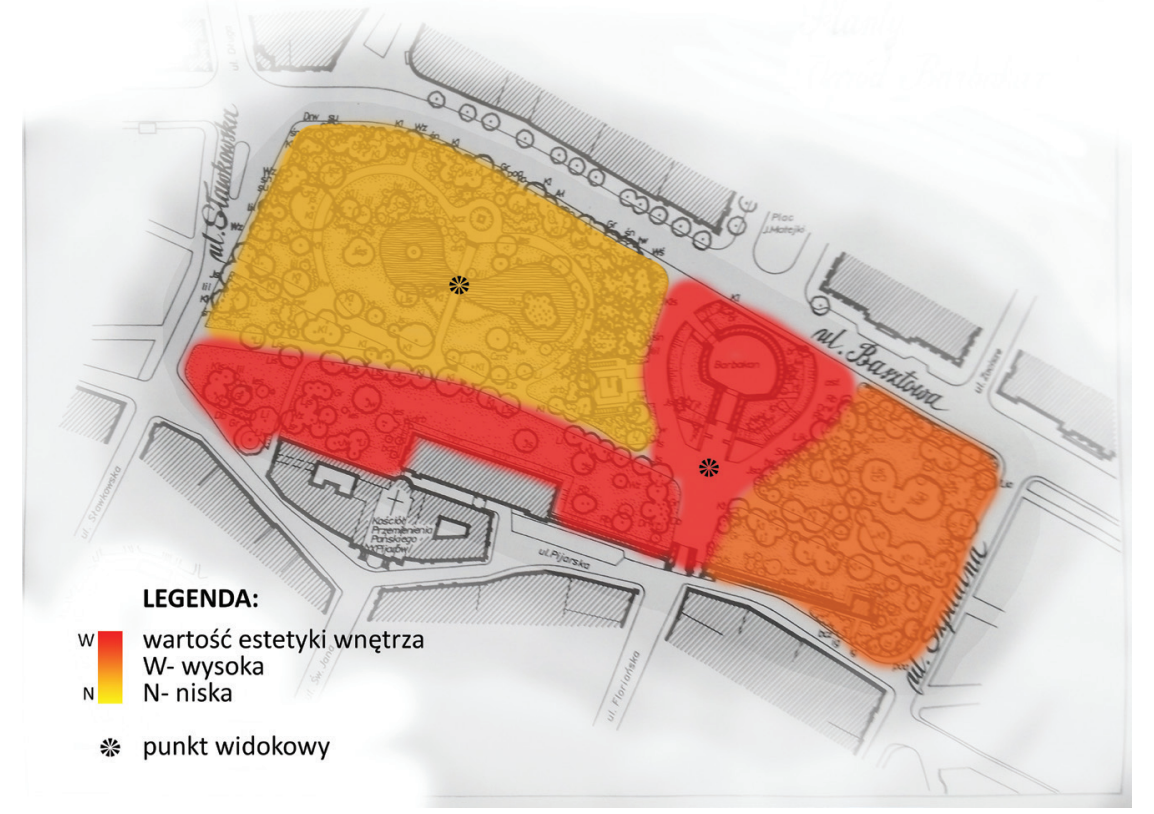

II. 7. Analiza waloryzacji wnętrza krajobrazowego Ogrodu Barbakan (opr. A. Greniuk) 


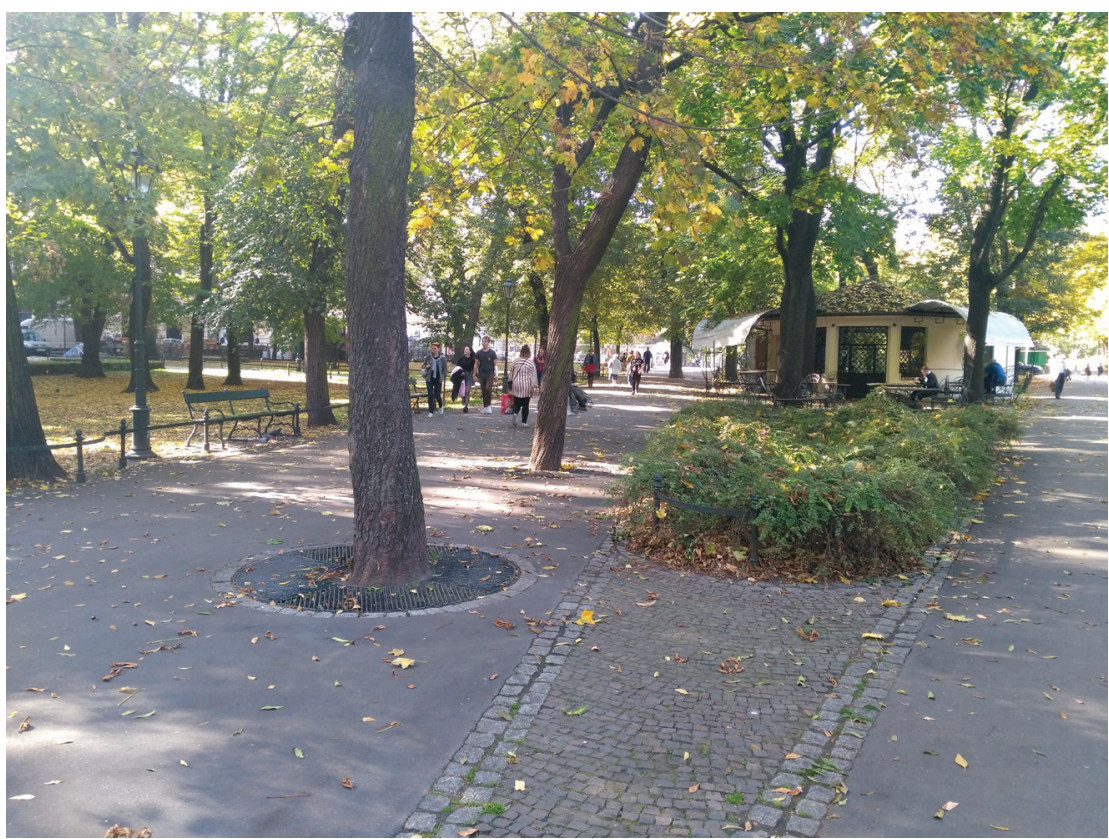

II. 8. Ścieżki w Ogrodzie Barbakan, pawilon kawiarniany w tle (fot. A. Greniuk)

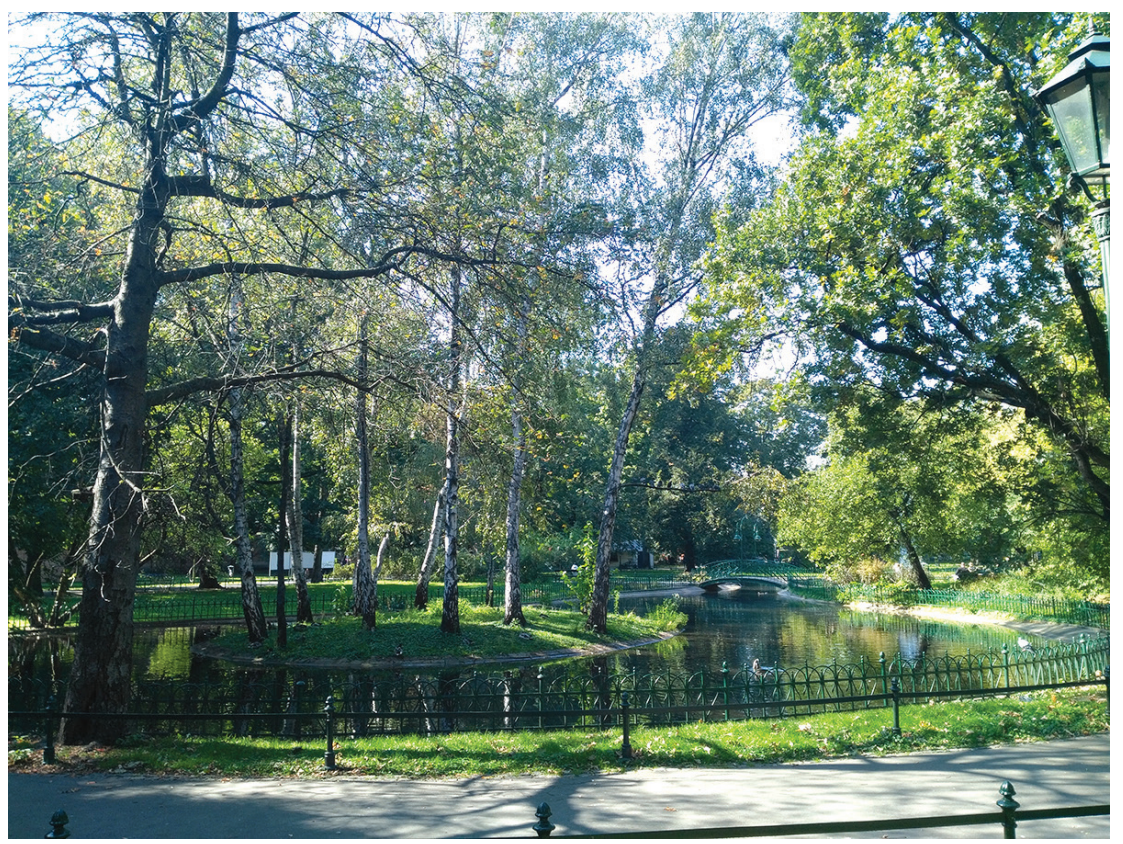

II. 9. Wnętrze krajobrazowe z sadzawką (fot. A. Greniuk) 
Konsultacje oraz wsparcie naukowe: dr inż. arch. Katarzyna Hodor, mgr inż. ogrodnictwa Katarzyna Fabijanowska

\section{PRZYPISY}

1 F. Klein, Planty Krakowskie, Wydawnictwo Towarzystwa Ochrony Piękności Miasta Krakowa i Okolicy, Kraków 1911, s. 13.

2 Słownik Wyrazów Obcych, red. nauk. J. Tokarski, Wydawnictwo PWN, Warszawa 1980, hasło plantunek, s. 577.

3 J. Torowska, Planty Krakowskie i ich przestrzeń kulturowa, Ośrodek Kultury im. Cypriana Kamila Norwida, Kraków 2012 (Parki Krakowa), s. 10.

4 F. Klein, op. cit., s. 17.

5 Ibidem, s. 22.

6 Ibidem, s. 39.

\section{BIBLIOGRAFIA}

Parki i ogrody Krakowa w obrębie Plant z Plantami i Wawelem. Katalog parków i ogrodów w Polsce, t. I, red. J. Bogdanowski, Ośrodek Ochrony Zabytkowego Krajobrazu, Narodowa Instytucja Kultury, Warszawa 1997.

Klein F., Planty Krakowskie, Wydawnictwo Towarzystwa Ochrony Piękności Miasta Krakowa i Okolicy, Kraków 1911.

Kozioł A., Na krakowskich Plantach: historie, obyczaje, anegdoty, WAM, Kraków 2008.

Słownik Wyrazów Obcych, red. nauk. J. Tokarski, Wydawnictwo PWN, Warszawa 1980.

Torowska J., Planty Krakowskie i ich przestrzeń kulturowa, Ośrodek Kultury im. Cypriana Kamila Norwida, Kraków 2012 (Parki Krakowa).

http://www.parki.org.pl/parki-miejskie/planty-krakowskie-ogrod-wawel (dostęp: 10.01.2019). http://www.starykrakow.com.pl/dawne-planty/historia_plant.htm (dostęp: 10.01.2019). 